\title{
Virología del Coronavirus
}

Coronavirus Virology

\section{*Norma Gonzáles Hernández}

\section{RESUMEN}

Pertenece a la familia coronaviridae y se designan bajo este termino a todas las especies pertenecientes a los géneros alfa, beta, gamma y deltacoronavirus. ${ }^{1} \mathrm{Su}$ nombre es dado por su forma de pequeña corona que presenta a su alrededor al ser vista por microscopia electrónica. Su superficie se caracteriza por proyecciones en forma de picos que están compuestas por una glucoproteína de alto peso molecular (proteínas Spike o S); y muestran antígenos específicos que se eliminan fácilmente por la enzima proteasa. 2 Las proteínas $S$ son la secuencia genómica más variable del virus; y se usa para la unión del receptor del huésped y, por lo tanto, la entrada del virus. Su genoma está formado por una única cadena de ARN con polaridad positiva (+SSRNA) y de aproximadamente 30,000 pares de bases, que presenta una cobertura metilada en el extremo 5' y una cola poliadenilada (poly A) en el extremo 3', dándole un gran parecido al ARN mensajero del hospedador y un diámetro de aproximadamente $120-160 \mathrm{~nm}$, que representa el mayor de los virus de ARN conocidos. Este virus se replica con la entrada de los viriones, siendo esta la forma infecciosa del virus, cuando pierden su envoltura y depositan su ARN viral en el citoplasma de la célula eucariota, donde el parecido con el ARNm del hospedador le permite adherirse directamente a los ribosomas para su traducción, usándose como plantilla directamente en la poliproteína 1a/1ab, en la cual están unidas todas las proteínas que formarán el complejo de replicación-transcripción en

\footnotetext{
*Gastroenteróloga pediatra.

Dirigir correspondecia a: cristandng@hotmail.com

Recibido: 10 de Septiembre de 2020 Aprobado: 1 de Octubre de 2020
}

vesículas de doble membrana. A partir de dicho complejo, se sintetizan diversos ARN subgenómicos codificantes para los polipéptidos y proteínas (estructurales y no estructurales) que determinan la biología del virus y la simetría helicoidal de su nucleocápside.

Figura 1. Morfología de los coronavirus.

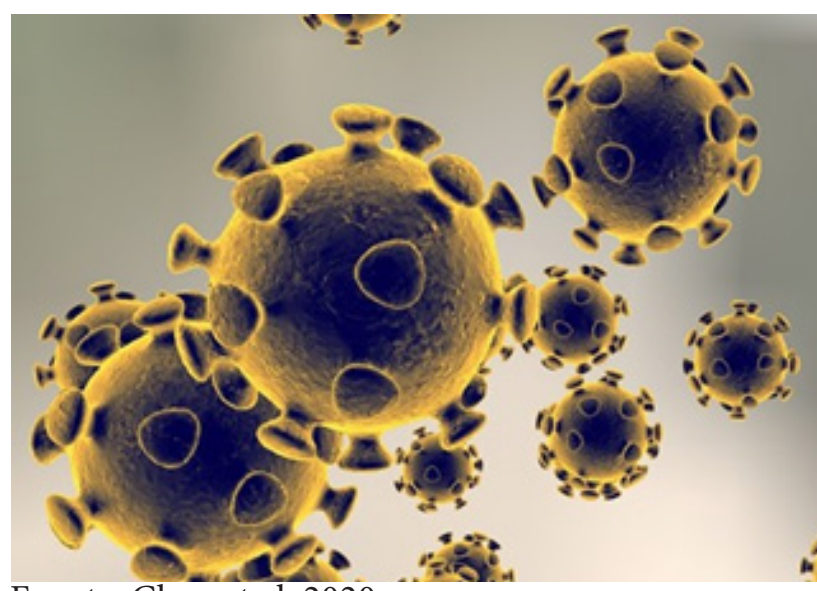

Fuente: Chen et al. 2020

\section{Transmisión}

Los coronavirus son virus zoonóticos, esto es, pueden transmitirse entre animales y humanos. Es decir, muchos coronavirus pueden usar a los mamíferos como reservorios u hospedadores intermediarios, destacando entre ellos los murciélagos, en losque sefacilitala recombinación y los eventos mutagénicos conducentes a una mayor diversidad genética de los virus. ${ }^{2}$ En la infección a mamíferos, los coronavirus infectan fundamentalmente células del tracto respiratorio y gastrointestinal. Existen diferentes especies de coronavirus que circulan entre animales pero que aún no han afectado a humanos. En 1960 se describieron por primera vez en las cavidades nasales de pacientes con resfriado común y hasta 
ahora, solo se conocían 6 especies de coronavirus que podían infectar a humanos $(\mathrm{HCoV})$ y causar enfermedades respiratorias: $\mathrm{HCoV}-229 \mathrm{E}$, HCoV-OC43, HCoV-NL63 y HKU1 provocan infecciones leves del tracto respiratorio superior. ${ }^{3}$ Son endémicos a nivel global y suponen un 10$30 \%$ de las infecciones del tracto respiratorio superior en adultos. Solo en casos raros pueden provocar infecciones graves en población pediátrica y adultos de edad avanzada.

Los más conocidos por su patogenicidad son el MERS-CoV (coronavirus causante del Síndrome Respiratorio de Oriente Medio) que se transmite al hombre desde dromedarios y el SARS-CoV (responsable del Síndrome Respiratorio Agudo y Severo), este último se transmitió por primera vez a humanos desde civetas (gato oriundo del sudeste asiático). Según análisis genéticos el nuevo coronavirus identificado en diciembre de 2019 pertenece al género betacoronavirus y guarda estrecho parentesco estructural con SARS-CoV. Fue provisionalmente denominado 2019-nCoV, pero ha sido bautizado posteriormente por la OMS como SARS-CoV-2.1

El brote surgió en la ciudad china de Wuhan, una metrópoli de 11 millones de habitantes en la provincia de Hubei, el 19 de diciembre de 2019, donde las autoridades locales inicialmente refirieron un origen desconocido del brote, pero posteriormente se relacionó con un gran mercado de animales y mariscos de esa ciudad. Epidemiológicamente, ocho de los nueve pacientes en un estudio tenían antecedentes de exposición al mercado de mariscos de Huanan en Wuhan, lo que sugiere que podrían haber estado en contacto cercano con la fuente de infección. Sin embargo, un paciente nunca había visitado el mercado, aunque se había alojado en un hotel cerca del mercado antes del inicio de su enfermedad. Este hallazgo sugiere una posible transmisión de gotas o que el paciente fue infectado por una fuente actualmente desconocida. La via principal de transmisión de persona a persona es por gotas de saliva de tamaños variables emitidas por los pacientes a una distancia de hasta 1-1.5 metros y pueden permanecer durante mucho tiempo en el entorno inmediato de los pacientes e infectar a otras personas. ${ }^{4}$ La transmisión indirecta puede ocurrir al manipular los objetos contaminados y luego tocar la nariz, boca u ojos. Ya que el virus se transmite de individuo a individuo se necesita urgentemente una vigilancia clínica de su mutación.

\section{Patogénesis}

El virus COVID-19 es un ARN monocatenario con una enzima transcriptasa inversa formada por dos poliproteínas ppla y pplab que comprenden 16 proteínas no estructurales. El coronavirus SARS-CoV-2 entra en las células a través de la unión de una proteína de su superficie, la proteína $\mathrm{S}$, con el receptor ACE-2 (enzima convertidora de angiotensina 2) de las células huésped ${ }^{5}$; luego el virus gana membranas dobles del retículo endoplásmico rugoso (RER) de la célula huésped. Las proteínas virales no estructurales reorganizan las membranas obtenidas para formar vesículas virales en las que ocurre su replicación, que dura aproximadamente una semana, y su transcripción, periodo en el que el tropismo a las células de la vía aérea superior es responsable de la eliminación viral y de la alta infectividad de los pacientes; llegando al sistema respiratorio inferior y al torrente sanguíneo. En el pulmón invade los neumocitos tipo II que transportan la enzima ACE2; aquí se replica produciendo su destrucción y la consiguiente pérdida de producción de surfactante que protege al pulmón del colapso. En el torrente sanguíneo COVID-19 invade los linfocitos $\mathrm{B}, \mathrm{T}$ y las células asesinas naturales (NK) evidenciándose esta en una marcada disminución del recuento linfocitario. El mecanismo de destrucción que induce el virus aun no esta claro, sin embargo se ha encontrado disminución en las células $\mathrm{T}$ CD4+ pero un aumento relativo en las T CD8+; la destrucción de estos linfocitos podría provocar una respuesta tormentosa del sistema inmune representada por un aumento de IL-6, proteína C reactiva (PCR), fibrinógeno, e hipercoagulabilidad sanguínea. Esta última podría inducir la formación de trombos en otras partes del cuerpo, incluidos pulmones, coronarias con posible morbilidad. La 
tormenta de citocinas además de baja inmunidad causada por la disminución de linfocitos y células NK puede ser responsable de la neumonía grave. Debidoa quela proteínaS esla secuenciagenómica mas variable del virus, una variante del SARSCOV2 que lleva el cambio de aminoácidos de la proteína S D614G a G614, fue estadísticamente significativa, lo que sugiere que la variante G614 puede tener una ventaja en individuos infectados, G614 se asocia con umbrales de ciclo de PCRTR más bajos, lo que sugiere cargas virales más altas del tracto respiratorio superior, pero no con una mayor gravedad de la enfermedad; lo cual nos ayuda en la comprensión del virus y en la vigilancia continua de las mutaciones de la proteína Spike y en el desarrollo de vacunas. ${ }^{6}$

\section{REFERENCIAS BIBLIOGRÁFICAS}

1. Consejo General de Colegios Farmaceuticos. (May de 2020). Portalfarma. Obtenido de https://www.portalfarma.com/Profesionales/ campanaspf/Asesoramiento-salud-publica/ infeccion-coronavirus-2019-nCoV/Documents/ Informe-tecnico-Coronavirus.pdf

2. World Health Organization. (May de 2020). Obtenido de World Health Organization: www.who.int/emergencies/diseases/novelcoronavirus-2019/situation-reports

3. Hegazy, Abdelmonem \& Hegazy, Raafat. (2020). COVID-19: Virology, Pathogenesis and Potential Therapeutics. Afro-Egyptian Journal of Infectious and Endemic Diseases. 10.10.21608/ AEJI.2020.93432.

4. Roujian L. et al., Genomic characterisation and epidemiology of 2019 novel coronavirus: implications for virus origins and receptor binding. The Lancet. 2020;395:565-574. https:// doi.org/10.1016/S0140-6736(20)30251-8

5. TolosaA.CoronavirusSARS-CoV-2: estructura, mecanismo de infección y células afectadas [Internet]. Genotipia. 2020 [cited 22 September 2020]. Available from: https://genotipia.com/ genetica_medica_news/coronavirus-estructurainfeccion-celulas/

6. Korber et al., Tracking Changes in SARSCoV-2 Spike: Evidence that D614G Increases Infectivity of the COVID-19 Virus, Cell (2020), https://doi.org/10.1016/j.cell.2020.06.043 